УДК 636.39:619:616.99:619:615

(C) 2013

Корчан Л. М., кандидат ветеринарных наук,
Корніснко М. В., студентка У курсу ФВМ

Полтавська державна аграрна академія

\title{
СТРОНГІЛОїДОЗ У КІз
}

\section{Рецензент - кандидат ветеринарних наук О. В. Кручиненко}

Наведені дані щзодо поширення, вікової динаміки строгілоїдозу у кіз в особистих підсобних господарствах Лубенського району Полтавської області (EI-42\%, II - 147,2 яєць у 1 г фекалій та 232,5 личинок у 5 г фекалій, найвища екстенсивність стронгілоїдозної інвазії відмічається у молодняку кіз 912-місячного віку - 85,0\%), гематологічні зміни, а також вивчена ефективність антигельмінтиків групи макроциклічних лактонів - «Івермеквету» $1 \%$-го і комбінованих препаратів - «Комбітрему» и «Рафензолу» за даної інвазії.

Ключові слова: стронгілоїдоз, кози, антигельмінтна ефективність.

Постановка проблеми. Стронгілоїдоз є одним із найпоширеніших гельмінтозних інвазій у кіз. Хворіє на стронгілоїдоз і людина $[1,6]$. Захворювання спричиняється нематодою виду Strongyloides papillosus родини Strongyloididae, супроводжується запаленням та набряками шкіри, діареєю, бронхопневмонією, пригніченням імунної системи господаря внаслідок дефіциту Т-лімфоцитів [5-7]. Хвороба частіше протікає в хронічній формі, проявляється зниженням приросту маси тіла, м'ясної й молочної продуктивності та відставанням у рості й розвитку, що завдає значних економічних збитків господарствам і підвищує ризики ураження людей. За гострого перебігу стронгілоїдозу може спостерігатися загибель тварин, особливо молодняку $[1,6]$.

Окремі автори зазначають, що зараження кіз на стронгілоїдоз починається вже 3 двотижневого віку $[5,6]$.

Аналіз останніх досліджень і публікацій, у яких започатковано розв'язання проблеми. Проблема стронгілоїдозу дрібної рогатої худоби, зокрема кіз, тривалий час залишалася поза полем зору науковців. Та інформація, що стосується даної інвазії, висвітлює переважно проблеми вівчарства [1, 6-7].

За окремими літературними даними, екстенсивність даної інвазії серед кіз у світі становить близько 11-24\%, а в країнах із тропічним кліматом та у сільській місцевості цей показник сягає у середньому 35 \% [5-7].
На сьогодні для боротьби 3 даним захворюванням пропонується чимало антигельмінтних препаратів, однак стронгілоїдоз у кіз продовжує залишатися досить актуальною й маловивченою проблемою $[5,6]$.

Мета даної роботи полягала у вивченні поширення, вікової динаміки строгілоїдозу у кіз, які утримуються в умовах особистих підсобних господарств; 3'ясуванні гематологічних змін за даної інвазії та визначенні ефективності антигельмінтиків групи макроциклічних лактонів - «Івермеквету» 1 \%-го і комбінованих препаратів - «Комбітрему» й «Рафензолу».

Завдання - знизити поширення стронгілоїдозної інвазії у кіз і зменшити ризик зараження людини.

Матеріали і методи досліджень. Дослідження проводили протягом 2013 року з використанням проб фекалій від 108 кіз віком від одного до семи років і молодняку від семиденного віку, які належать власникам особистих підсобних господарств Лубенського району Полтавської області.

Для гельмінтокопрологічних досліджень у кіз індивідуально відбирали проби фекалій із прямої кишки за допомогою приладу для відбору проб фекалій у дрібної рогатої худоби [3].

Гельмінтоовоскопічні дослідження проб фекалій проводили за способом Котельникова i Хренова з використанням у якості флотаційного розчину аміачної селітри 3 густиною 1,295. Підрахунок яєць гельмінтів проводили в трьох краплях флотаційного розчину й робили перерахунок для визначення інтенсивності інвазії в 1 г фекалій [4].

Гельмінтоларвоскопічне дослідження визначали за кількісним гельмінтоларвоскопічним методом із підрахунком личинок у лічильній камері [3]. Паралельно виконували метод послідовних промивань [4].

Гематологічні дослідження крові проводили за загальноприйнятими методами [2].

За результатами гельмінтокопрологічних досліджень 3 урахуванням принципу аналогів 


\section{ВЕТЕРИНАРНА МЕДИЦИНА}

нами було сформовано сім груп тварин (шість дослідних і контрольна), яким згідно з діючими настановами до застосування вводили:

- першій групі кіз (n=10) - «Івермеквет» 1 \%, підшкірно одноразово, в дозі 1 мл/50 кг маси тіла тварини;

- другій групі тварин (n=10) - «Комбітрем», перорально одноразово, в дозі 5 мл/50 кг маси тіла;

- третій групі кіз (n=10) - «Рафензол», перорально одноразово, в дозі 0,75 мл/10 кг маси тіла;

- четвертій групі тварин (n=10) - «Івермеквет» $1 \%$, підшкірно одноразово, в дозі 1 мл/50 кг маси тіла та 0,6\% теплий розчин молочної кислоти, внутрішньо одноразово, в дозі 500 мл на тварину;

- П’ятій групі (n=10) - «Комбітрем», перорально одноразово, в дозі 5 мл/50 кг маси тіла та відвар насіння льону, внутрошньо одноразово, в дозі 200 мл на тварину;

- козам шостої групи $(\mathrm{n}=10)$ - «Рафензол», перорально одноразово, в дозі 0,75 мл/10 кг маси тіла та 0,6 \% теплий розчин молочної кислоти, внутрішньо одноразово, в дозі 500 мл на тварину;

- сьома група $(n=10)$ була контрольною препарати козам не вводили.

Антигельмінтний препарат «Івермеквет» $1 \%$ відноситься до групи макроциклічних лактонів, містить діючу речовину - івермектин. «Комбітрем» та «Рафензол» відноситься до групи комбінованих антигельмінтних препаратів. Діючими речовинами «Комбітрему» є альбендазол та триклабендазол, а «Рафензолу» рафоксанід, фенбендазол та левомізолу гідрохлорид. Ефективність випробуваних антигельмінтиків досліджували за зміною показників екстенсивності (ЕI) та інтенсивності (II) стронгілоїдозної інвазії до і на 14-ту та 28-му добу після призначення препаратів. На основі отриманих даних визначали показники інтенс- та екстенсефективності (IE, EЕ) препаратів.

Результати досліджень. У процесі дослідження виявили, що екстенсивність стронгілоїдозної інвазії у кіз, залежно від їх віку, в середньому становила $42 \%$, інтенсивність інвазіі - 147,2 яєць у 1 г фекалій, а за кількісним гельмінтоларвоскопічним дослідженням 232,5 личинок у 5 г фекалій.

Результати вивчення вікової динаміки стронгілоїдозу кіз свідчать про те, що показники ЕI та II суттєво змінюються залежно від віку тварин. EI у молодняку кіз до трьохмісячного віку становила $10,0 \%$, віком 3-6 місяців - 20,0 \%, віком 9-12 місяців - 80,0-90,0\%, у кіз 1,5-3річного віку - $60 \%$, віком 4-7 років - $40 \%$.

Вперше личинки стронгілоїд виявляли у молодняку кіз трьохмісячного віку (II - 4 яєць у 1 г фекалій, 7 личинок у 5 г фекалій), віком 3-6 місяців (II - 15 яєць у 1 г фекалій, 36 личинок i3 5 г фекалій), віком 9-12 місяців (II - 73 яєць у 1 г фекалій, 227 личинок із 5 г фекалій). Найвищою II була у кіз 1,5-3-річного віку (151 яєць у 1 г фекалій, 316 личинок із 5 г фекалій) та віком 4-7 років (280 яєць у 1 г фекалій, 462 личинок із 5 г фекалій).

За клінічного обстеження кіз було виявлено: місцеві дерматити на кінцівках - у $12 \%$, підвищення температури тіла до $41,5^{\circ} \mathrm{C}$ iз погіршенням загального стану - $7 \%$, ознаки бронхопневмонії - $5 \%$, порушення роботи шлунково-кишкового тракту - 22 \%. У 54 \% кіз відмічався хронічний перебіг хвороби.

За гематологічного дослідження крові у кіз, хворих на стронгілоїдоз, виявляли еозинофілію (17\%), лейкоцитоз (21 Г/л), гіпорегенеративне зрушення нейтрофільного ядра вліво, підвищення швидкості осідання еритроцитів (у середньому 3 мм/год) та олігохромемію (близько 8 г/100 мл).

Результати гельмінтоларвоскопічних досліджень щодо визначення ефективності лікування кіз за умов спонтанного зараження їх стронгілоїдами, наведені в таблиці. Дані свідчать, що в тварин першої та четвертої груп, яким вводили «Івермеквет» 1 \% без та з 0,6 \% молочною кислотою, відмічається найкращий терапевтичний ефект уже на 14-ту добу після лікування (IE - $99 \%$, EE - 100 \%). На 28-у добу ефективність «Іівермеквет» $1 \%$ становила $100 \%$. У разі застосування «Рафензолу» у тварин третьої групи інтенсефективність становила на 14-й і 28-й день, відповідно, 34,7 \% і $49,4 \%$, а у тварин шостої групи (із застосуванням $0,6 \%$ молочної кислоти) цей показник збільшився на 6,6 \%. Препарат «Комбітрем», порівняно 3 «Рафензолом», показав дещо вищу інтенсефективність, особливо у тварин п'ятої групи, із застосуванням 0,6 \% молочної кислоти $(\mathrm{IE}=85,0 \%)$. Екстенсефективність «Рафензолу» та «Комбітрему» була практично не виражена. Після проведення дегельмінтизації клінічний стан тварин усіх шести дослідних груп не відрізнявся від тварин контрольної групи.

Перспективи подальших досліджень полягають у вивчені морфологічних і біохімічних показників крові кіз за використання антигельмінтика «Івермеквет» 1\%-го. 
BETЕРИНАРНА МЕДИЦИНА

Ефективність застосування антигельмінтних препаратів за стронгілоїдозу у кіз

\begin{tabular}{|c|c|c|c|c|c|c|c|c|}
\hline \multirow{4}{*}{$\begin{array}{c}\text { № } \\
\text { групи }\end{array}$} & \multirow{4}{*}{$\begin{array}{c}\text { Назва та доза } \\
\text { препарату }\end{array}$} & \multicolumn{7}{|c|}{ Показники інвазії } \\
\hline & & \multirow{3}{*}{$\begin{array}{c}\text { до лікування } \\
\text { II, лич. } \\
35 \text { г фекалій }\end{array}$} & \multicolumn{6}{|c|}{ після лікування } \\
\hline & & & \multicolumn{3}{|c|}{ через 14 днів } & \multicolumn{3}{|c|}{ через 28 днів } \\
\hline & & & $\begin{array}{c}\text { II, лич. } \\
35 \text { г } \\
\text { фекалій }\end{array}$ & $\begin{array}{l}\text { IE, } \\
\%\end{array}$ & $\begin{array}{c}\mathrm{EE}, \\
\%\end{array}$ & $\begin{array}{c}\text { II, лич. } \\
35 \text { г } \\
\text { фекалій }\end{array}$ & $\begin{array}{l}\text { IE, } \\
\%\end{array}$ & $\begin{array}{c}\mathrm{EE}, \\
\%\end{array}$ \\
\hline 1 & $\begin{array}{l}\text { «Івермеквет» 1\%, } \\
1 \text { мл/50 кг }\end{array}$ & 409,0 & 1,7 & 99,6 & 100 & 0 & 100 & 100 \\
\hline 2 & $\begin{array}{l}\text { «Комбітрем», } \\
5 \text { мл/50 кг }\end{array}$ & 421,5 & 121,0 & 71,3 & 10 & 93,6 & 77,8 & 20 \\
\hline 3 & $\begin{array}{l}\text { «Рафензол», } \\
0,75 \text { мл/10 кг }\end{array}$ & 393,1 & 256,7 & 34,7 & 0 & 198,9 & 49,4 & 10 \\
\hline 4 & $\begin{array}{l}\text { «Івермектин» } 1 \% \text {, } \\
1 \text { мл/50 кг, 0,6 \% } \\
\text { молочна кислота, } \\
500 \text { мл/тванину }\end{array}$ & 358,0 & 1,4 & 99,6 & 90 & 0,4 & 99,9 & 100 \\
\hline 5 & $\begin{array}{l}\text { комбітрем, } \\
5 \text { мл/50 кг, } \\
\text { відвар насіння льо- } \\
\text { ну, } \\
200 \text { мл/тварину }\end{array}$ & 362,9 & 96,2 & 73,5 & 10 & 54,4 & 85,0 & 30 \\
\hline 6 & $\begin{array}{l}\text { «Рафензол», } \\
0,75 \text { мл/10 кг, } \\
0,6 \text { \% молочна } \\
\text { кислота, } \\
500 \text { мл/тварину }\end{array}$ & 416,3 & 244,4 & 41,3 & 10 & 204,0 & 51,0 & 20 \\
\hline 7 & контроль & 360,0 & 308,3 & - & - & 371,5 & - & $\begin{array}{lllllllllllll}- & \end{array}$ \\
\hline
\end{tabular}

\section{Висновки:}

1. В особистих підсобних господарствах Лубенського району Полтавської області стронгілоїдоз у кіз є досить поширеною інвазією (ЕI $42 \%$, II - 147,2 яєць у 1 г фекалій та 232,5 личинок у 5 г фекалій).

2. Найвища екстенсивність стронгілоїдозної інвазії відмічається у молодняку кіз 9-12місячного віку $-85,0 \%$; із віком вона знижується. Інтенсивність даної інвазії, навпаки, з віком зростає й пік ії виявляється у кіз 4-7-річного віку - 280 яєць у 1 г фекалій, 462 личинок із 5 г фекалій.

\section{БІБЛІОГРАФІЯ}

1. Капитонова В. А. Стронгилоидоз овец, эпизоотология, диагностика и терапия: дис. ...к.вет.н. : 03.00.19: «паразитология» / В. А. Капитонова. - Казань, 1980. - 129 с.

2. Кудрявиев A. А. Клиническая гематология животных / А. А. Кудрявцев, Л. А. Кудрявцева. М. : Колос, 1974. - 339 с.

3. Методичні рекомендації щодо гельмінтоларвоскопічних досліджень стронгілятозів у дріб-
3. За гематологічного дослідження крові у кіз, хворих на стронгілоїдоз, виявляли еозинофілію $(17 \%)$, лейкоцитоз (21 Г/л), гіпорегенеративне зрушення нейтрофільного ядра вліво, підвищення швидкості осідання еритроцитів (у середньому 3 мм/год) та олігохромемію (близько 8 г/100 мл).

4. Найбільш ефективним антигельмінтним засобом за стронгілоїдозу у кіз $є$ препарат із групи макроциклічних лактонів - «Івермеквет» $1 \%$, ефективність якого на 28-му добу за одноразового підшкірного введення в дозі 1 мл/50 кг маси тіла тварини становила $100 \%$.

ної рогатої худоби / Ю. О. Приходько, Л. М. Корчан, Ю. О. Приходько [та ін.] - Полтава, 2013. $28 \mathrm{c}$.

4. Рекомендації щодо гельмінтологічних досліджень тварин / С. І. Пономар, Н. М. Сорока, О. П. Литвиненко [та ін.] - Біла Церква, 2008. $78 \mathrm{c}$.

5. Чемоданкина Н. А. Стронгилоидоз овец в Саратовской области (распространение, меры 


\section{ВЕТЕРИНАРНА МЕДИЦИНА}

борьбы): дис. ... к.вет.н. : 03.00.19: «паразитология» / Чемоданкина Наталия Анатольевна. - Caратов, 2007. - $130 \mathrm{c}$.

6. Ziomko I. Experimental invasion of Strongyloides papilosus in sheep // Bulletin of the Veterinary Institute in Pulawy. - 2000. - V. 44. - P. 179-186.
7. Nwaorgu O. C., Onyali I. O. Strongyloides papillosus: prenatal and transmammary infection in ewes // Revue d'élevage et de medicine vétérinaire des pays tropicaux. - 1990. - V. 43 (4). - P. 503504. 